\title{
KOHTEKCT
}

УДК 008

ББК 71.1

DOI 10.25281/2072-3156-2018-15-3-260-270

\section{В.С. ЛЕВИЦКИЙ}

\section{ЛОГИКА ИСТОРИИ ЗАПАДА: ТРИ ЭПОХИ}

\section{Виктор Сергеевич Левицкий,}

Украинский институт стратегий глобального

развития и адаптации,

директор

Сечевых Стрельцов ул., 68-а,

Киев, 04050, Украина

кандидат философских наук

E-mail: uisgda@gmail.com; victor2609@ukr.net

Реферат. Постмодернистский поворот последней четверти XX в., заключавшийся в окончательном отказе от гранднарративов, превращает великие философские системы в одну из областей мифологических повествований. Однако этот факт не отменяет необходимости осмысления современной ситуации, ставшего неотьемлемым атрибутом идентичности модерна. На этом пути все большую значимость приобретают универсализирующие метафоры, обобщающие знание на интуитивном уровне эстетического восприятия. С точки зрения такого философско-метафоричного инструментария историю Запада схематично можно описать в виде трех эпох, символами которых соответ- ственно выступают Ум (разум), Рассудок, Чувственность, каждой из которых свойственны уникальные системообразующие смыслы, предполагающие релевантные им культурные практики. Ум, или эпоха Античности, утверждает тождественность несокрытого в реальности с онтологической основой существующего - космическим умом. Христианское Средневековье возводит грань между миром божественных архетипов и грешной эмпирией. Уделом и символом человеческого становится Рассудок. Новая эпоха (модерн) сосредоточивается на происходящем здесь и сейчас, сводит реальность к сиюминутному и прагматичному, а потому может быть описана как эпоха Чувственности. Понимаемая таким образом логика истории Запада позволяет по-новому посмотреть на весь исторический процесс, в то же время противопоставив ее (логику) ставшему классическим со времен М. Вебера взгляду на историю как на поступательный процесс расколдования, в результате которого человечество телеологически движется к воплощению формальной рациональности.

Ключевые слова: реальность, идентичность, чувственность, рассудок, разум, эпоха. 
Для цитирования: Левицкий В.С. Логика истории Запада: три эпохи // Обсерватория культуры. 2018. Т. 15, № 3. C. 260-270. DOI: 10.25281/2072-3156-2018-15-3-260-270.

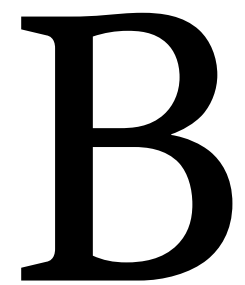

ремя гранднарративов безвозвратно кануло в Лету после постмодерного крестового похода против любых идеологий, теории, подобные системам Г. Гегеля и Ф. Шеллинга $[1 ; 2]$, наверное, уже невозможны в рамках современного философского дискурса. Построения К. Маркса, О. Шпенглера или А. Тойнби [3-5] в философско-исторической части выглядят сегодня, скорее, как лучшие образцы мифологического жанра; даже позитивистские концепции все большего прогресса человечества, опирающегося на науку, не выдерживают верификации практикой современности. При этом неотъемлемой составляющей западной идентичности является саморефлексия, в том числе и предельных масштабов. Поэтому, например, М. Хайдеггер [6], один из ярчайших представителей современной философии, считал вопрос логики развития Запада одним из центральных в своем творчестве; К. Ясперс [7], коллега фрайбургского ректора, посвятил трехтомное исследование «Философия» анализу этой же проблематики. Более того, например, торжественный манифест либерализма - работа Ф. Фукуямы о конце истории [8] - является результатом осмысления внутреннего принципа развития Запада уже в новейших условиях, а часть творчества Р. Рорти непротиворечиво можно отнести к жанру, против которого он так рьяно выступал [9]. Или другой пример из философии начала XXI в. - теории онтикологиков с Б. Латуром во главе, который, отрицая устоявшийся взгляд на природу модерна, пытается переосмыслить его основания, отказывая при этом в существовании Новому времени [10].

В связи с этим следует признать, что единая концепция, объясняющая всю тотальность бытия, подобно гегелевской системе, в современных условиях невозможна, однако исследования, пытающиеся отыскать логику развития социального мира, являются такой же частью современного философского дискурса, как, на- пример, исследования по искусственному интеллекту или философским проблемам языка.

Языком саморефлексии Запада стал концептуальный инструментарий исторической науки. Можно сказать, что именно та часть человечества, которая склонна к осмыслению собственной сути и предназначения в терминах философии истории, и является Западом. Логика развития исторического нарратива превращает общественную память в цементирующую основу западной идентичности, опирающейся на светское мировоззрение и секуляризированные ценности. Собственно, это рационализированное в свете лучей исторического разума культурное пространство и выступает ареной глобализации, часть за частью отрывая от материка традиционной цивилизации новые земли. С этой точки зрения Запад локализован уже давно не только на «западе», в той или иной степени он вбирает в себя культурные пространства Нового Света, Австралии и Азии.

Сама же универсализирующая культурную идентичность логика исторического разума зарождается в религиозно-мифических построениях христианских визионеров, и поступательно очищаясь от христианских одеяний, обретает трансцендентально-метафизические формы в трудах европейских мыслителей. Показательно, что архиважные для судьбы XX в. учения Шеллинга и Гегеля в значительной степени воскрешают мистические построения, характерные для бурных эпох в развитии христианства - времен борьбы с гностиками [11] и кризиса XI-XIV вв., связанного со становлением парадигмы секулярного разума. В частности, сформулированная в поздней философии Шеллинга теория «мировых эпох», согласно которой история проходит через эпохальные стадии Отца, Сына и Святого Духа [2], практически дословно повторяет мистическую историософию Иоахима Флорского. Параллельно шеллинговской теории разрабатываются и более соответствующие духу XIX в. «логики истории», например, теория Закона трех стадий О. Конта, согласно которой «каждое из наших основных понятий проходит, необходимым образом, три теоретически различных стадии: стадию теологическую, или фиктивную; стадию метафизическую, или абстрактную; стадию научную, или позитивную... Отсюда три 
типа философии, или концептуальных систем, обобщающих феномены, взаимно исключающих друг друга. Первая - начальный пункт, необходимый для человеческого понимания (intelligentia), третья - фиксированная и определенная стадия, а вторая уготована служить в качестве транзитного пункта» [12, с. 561].

Теории, подобные приведенным выше, повлияли на разработку различных типологий культур, распространяющих шеллинговско-гегелевскую схему на историю развития известных из истории цивилизаций (например, Н.Я. Данилевского [13], О. Шпенглера [4], А. Тойнби [5] и т. д.), а также дали импульс для новых обобщений. Одним из наиболее интересных следует признать типологию П. Сорокина, осуществленную в работе «Социокультурная динамика». В ней американско-российский социолог выделяет в истории три вида культуры, связанных с тремя типами истины: чувственный, идеациональный и идеалистический. «Чувственная истина суть истина чувств, постигаемая органами чувственного восприятия». Она связанна с утилитарностью и гедонистичностью. «Идеациональная истина - это истина, открываемая милостью Божией через его глашатаев (пророки, мистики, «отцы церкви»), обнаруживаемая сверхчувственным способом посредством мистического опыта, прямого откровения, божественной интуицией и вдохновением. Такая истина может быть названа истиной веры». Она воспринимается непогрешимой и указывает на подлинные ценности. «Идеалистическая истина, - пишет П. Сорокин, - есть синтез двух других истин, т. е. синтез, созданный нашим разумом» [14, с. 462].

Настоящая статья рассматривается нами как часть философско-исторического дискурса, в которой предпринимается еще одна попытка обобщения логики развития западной цивилизации.

Схематично историю Запада можно описать в виде трех эпох, символами которых соответственно выступают Ум (разум), Рассудок, Чувственность. Каждой из них свойственны уникальные системообразующие смыслы, предполагающие релевантные им культурные практики.

Платон около двух с половиной тысяч лет назад описал структуру познавательной способ- ности человека, определив тем самым ее форму для всей последующей интеллектуальной истории Запада. В диалоге «Государство» он выделил: чувственность, имеющую дело с ощущениями и не способную познать истину, а выступающую основанием для мнения; рассудок, способность к дискурсивному мышлению, двигающемуся от одной посылки к другой и производящему максимум геометрические истины; ум (разум) как высшую способность человека, позволяющую созерцать истинносущий мир идей. Такое деление основывается на метафизике Платона (являющейся частным вариантом культурной метафизики), согласно которой существует истинный мир идей - вечно прекрасный, неподвижный, где бытие есть мышление; мир же чувственный является несовершенным отражением истинного мира, он вечно текуч и изменчив, не содержит ничего постоянного, иллюзорен. Соответственно знать (и желать) можно только истинный мир путем умного зрения (созерцания) идей. В диалоге «Федон» Платон указывает, что только умом душа может прикоснуться к истине, чувственность же наоборот - помеха в этом процессе: «Но мыслит она (душа. - В. Л.) лучше, вероятно, тогда, когда ничто не беспокоится - ни слух, ни зрение, ни печаль, ни удовольствие, когда, оставив тело и, сколько возможно, удалившись от общения с ним, она бывает совершенно одна, сама по себе, и стремится к сущему» [15, с. 116-117]. А дальше Сократ вопрошает об истинном познании: «А подобный результат не тот ли обретет лучше, кто будет обращаться к каждому предмету именно одной мыслью, не присоединяя к размышлению зрения и не увлекая за умом никакого другого чувства; кто будет пользоваться просто мыслью, самой по себе, и постарается уловить каждое сущее, само по себе, непременно отказавшись и от глаз, и от ушей, и, так сказать, от всего тела, поскольку своим участием оно возмущает душу и не позволяет ей приобрести истину и разумение?» [15, с. 117], и Симмий дает ему строго утвердительный ответ.

Для периода истории Запада, символом которого выступает Ум, чувственность - не «помощник» в познании истины, скорее, наоборот, может только отвлекать от созерцания истинносущего мира, который один только и стоит внимания и познания. Сущностной харак- 
теристикой ума и является именно то, что он не размышляет и путем умозаключения приходит к истине, он способен непосредственно ее созерцать. Ум не отыскивает истину, а видит, он направлен на сверхчувственное, на истинносущее бытие, поэтому чувственность для него лишь преграда. Следовательно, чувственного нужно сторониться, всего изменчивого избегать и не полагаться на данные ощущений, ибо они имеют дело с иллюзорным миром. Это, можно сказать, центральный этос эпохи Разума, вокруг которого формируются канонические культурные смыслы, определенные культурные практики, которые и формируют сам тип культуры. В иерархии сущих чувственный мир занимает низшее положение, и чем выше ум поднимается в этой иерархии, тем меньше материальности он встречает и тем больше постоянства находит. Главная категория этой эпохи - постоянство, единственный способ познать истину - ум, основное желание человека - слиться с Единым.

Плотин, представитель позднего периода эпохи Разума, обладая куда большим культурным материалом, чем его великий предшественник, довел это ощущение до предельных форм: единственное, что его интересует - «умная молитва» Единому, которой, по большому счету, являются все его Эннеады. В трактате «О Едином», пожалуй, главном его произведении, которое воспринимается, скорее, как поэзия или молитва, Плотин пишет: «Тогда, поскольку то, что мы ищем, - Единое, и мы рассматриваем Начало всех вещей, Благо и Первое, то не следует уходить далеко от вещей, окружающих первичных сущих, ниспадая к последним из всех, но, напротив - должно идти к первым, вознося себя от вещей чувственных - последних из сущих... Значит, [ищущему Единое] должно стать Умом, вверить Уму свою душу и прочно утвердиться на нем, чтобы душа могла пробудиться к приятию того, что видит Ум, и могла благодаря этому Уму увидеть Единое без прибавления чувственного восприятия, чтобы [душа] могла не принять ничего от чувства, будучи в том Уме, но видела бы чистым умом Наичистейшее и первичное чистого Ума» [16, с. 299-300].

Эта цитата дает хорошее понимание того, что описываемую эпоху не интересовало ни- что чувственное ${ }^{1}$, никакие изменения не были ей важны. Искусство того периода стало образцом для последующих двух с половиной тысяч лет не потому, что греки наиболее тонко копировали красоту этого мира, эталоном для них был совсем другой идеал. Поэтому скульптуры Поликлета - это не иллюстрация красоты тел этого мира, а воплощение вечной красоты (идеи), которая никогда не меняется. Исследователи не случайно указывают, что скульптуры Поликлета находятся в равновесии, без движения - воплощенная красота чужда какому-либо изменению. Поэтому все войны - это копия уже состоявшейся легендарной Троянской войны, а все путешествия - повторения странствий Одиссея. Золотой век - это дело давно минувших дней, а «история» все дальше отдаляется от совершенства, приближаясь к всемирному пожару. Поэтому Сократ спокойно принимает яд, отрицая даже саму идею иного выбора, ибо знает, что из мира изменений перемещается в мир постоянства, в мир истины и блага. Отыскать же эту истину в подлунном мире можно только умом, только ум может видеть идею, соответственно, правильная жизнь должна строиться на основе разума. И Платон, с одной стороны, верил, что того, кто однажды видел истину, уже никогда не будет интересовать чувственный мир, с другой - настаивал, что причина дурного поведения - отсутствие знания: тот, кто знает, что такое добро, дурно не поступает. В связи с этим культурные практики эпохи Разума построены вокруг умного знания, именно оно - ключ к построению справедливого государства, в котором управлять должны те, кто лучше всех «видит» идеи, кто ближе к истине. Именно в разуме без примеси чувств можно найти ответы на все предельные вопросы, в конце концов, существует только то, что познается умом - остальное бренность, остальное случайность. Именно при помощи разума можно надеяться слиться с тем, что выступает как вечный «предмет желания и предмет мысли» [17, с. 362].

Эпоха, символом которой можно считать Рассудок, стала возможна благодаря новому

1 «Чувственное» в нашем современном понимании, а не в понимании античного «телесно-чувственного», о котором так много писал А. Лосев, см. подробнее: [18]. 
взгляду на мир и человека, открытому христианским Откровением. Хотя святые отцы в вопросе познания истины в большей степени следовали еще за Платоном, настаивая на том, что знать можно только идеи, и указывая, что если бы у нас была возможность, как у ангелов, непосредственно созерцать эйдосы, наше бы знание вещей не отличалось от знания, полученного естественным путем ${ }^{2}$. В то же время они доказывали, что платой за грех стала невозможность созерцать сверхчувственный мир, в силу чего место ума, непосредственно видящего идеи, занял рассудок, вынужденный добывать знание путем анализа и рассуждения, основанного на дедуктивном рассуждении (из Библии) и чувственном опыте. Во времена высокой схоластики такая позиция получила новое, основанное на философии Аристотеля обоснование. Можно сказать, что канонизация новой культурной парадигмы происходила с двух сторон.

Во-первых, переосмысление аксиологического статуса тварного мира. Христианская догматика недвусмысленно указывала на то, что мир является делом рук Господа, который создал его исключительно из любви и сам признал, что получилось «хорошо весьма» [Быт. 1:31]. Соответственно, нельзя просто отворачиваться от него, как от недостойного: творение ценно, ибо оно божье творение. При этом, в противоположность сакрализму, каждое действие в этом мире может быть богоугодным, ибо, по словам апостола Павла, «едите ли, пьете ли, или иное что делаете, все делайте в славу Божию» [1 Кор. 10:31]. До определенной степени позднее это станет центральной максимой протестантской хозяйственной этики.

Во-вторых, развитие катафатического богословия, глубинное желание знать Бога, хотя бы по аналогии, при этом, например, Фома Аквинский совершенно четко понимал, что знание Бога возможно только по благодати [19]. Коль творение - это произведение Господа, соответственно и о его Творце можно нечто узнать, исходя из изучения самого творения. И необходимыми элементами здесь становятся чувственность и рассудок.

Фома Аквинский задается вопросом о связи вечного и преходящего в нашем познании

\footnotetext{
${ }^{2}$ Подробнее об этом см.: «Исповедь» Августина.
}

и отвечает следующим образом: «Итак, эти два рода, а именно вечное и преходящее, связаны с нашим познанием таким образом, что каждый из них служит средством для познания другого. Так, путем рассуждений мы от познания преходящего приходим к познанию вечного, ибо, согласно апостолу “невидимое Его чрез рассматривание творений видимо” $[19$, c. 109]. Опираясь на канонический текст Писания, он обосновывает возможность познания Бога по творениям его, наделяя таким образом творение новым невиданным статусом аподиктического элемента богопознания. Видимое становится ключом к познанию невидимого, происходит реабилитация чувственности: если раньше она только мешала умному зрению, то теперь, в силу несовершенства человеческого ума и его низкого положения, даже по отношению к ангелам, становится входными воротами в знание сверхчувственного. Через мир дольний видим мир горний. Дунс Скот лаконично формулирует новый принцип: «...чувство не чувствует ничего, кроме ощущаемого; следовательно, и разум не познает ничего, кроме того, образы чего он может обрести через чувства» [20, с. 399]. Знание возможно только на основе эмпирического опыта: то, чего сторонились представители эпохи Ума, стало главным предметом интереса во времена доминирования рассудка.

Окончательный шаг, эксплицировавший появление новой реальности, был сделан другим британским августинианцем - У. Оккамом. Развивая номиналистическую традицию, он однозначно отказывает в субстанциональности универсалиям: не существует ничего, что обозначается универсалией иначе, нежели в уме, «никакая универсалия не есть никакая субстанция, существующая вне души...» [21, c. 119]. Идея - это не самостоятельная субстанция, служащая образцом для чувственного мира, а слово, полученное путем абстрагирования и выделения чтойности из самой этой материальности. Следовательно, необходимо изучать эмпирическую действительность, которая единственно только и поддается познанию и служит материалом для получения общих понятий.

Таким образом, столкнувшись с тем, что непосредственное созерцание божественных 
идей в рамках христианского учения оказалось закрытым, был открыт иной путь к познанию универсалий, лежащий через рассудок: то, что раньше было прерогативой ума, стало функцией рассудка. Умозрение уступило место рассуждению.

В ходе этой культурной революции была открыта новая реальность - «природа», которая выступила необходимым элементом богопознания. Вместе с этим был обнаружен адекватный этой реальности «инструмент» рассудок, оказавшийся очень эффективным в деле освоения нового пространства. Этим и объясняется появление новой методологии взаимодействия с эмпирической действительностью - экспериментального естествознания, одним из родоначальников которого справедливо считают Р. Бэкона [22]. Если знать можно только частное, а общее образуется в «душе» на основе чувственных данных, то нужно направить все усилия на исследование того самого чувственного эмпирического мира, который является основой получения универсалий.

Следы «воплощения» символа рассудка в это время можно найти не только в появлении зачатков опытного естествознания прототипа науки Нового времени, основные культурные практики данного периода построены на этосе рассудка. Об этом свидетельствует бурное развитие европейских университетов, в которых происходит оттачивание данной рассудочной методологии. Само появление схоластики можно квалифицировать как идеальную утонченную практику, научающую филигранно пользоваться рассудком. Она является, с одной стороны, ответом на те культурные интуиции, которые витали в воздухе в те времена, с другой - практикой окончательной их экспликации и кодификации как культурных норм. Готика - это не просто воспарение от чувственности в божественную высь, - готический собор по форме удивительно напоминает структуру средневековых сумм, в которых автор/читатель не одномоментно узнает истину, а постепенно «вскарабкивается» при помощи единственного инструмента - рассудка от мнений ложных к знанию истинному. Полифония - также открытие этого периода, равноправие голосов - следствие аксиологическо- го равенства творения, в котором каждая тварь может по-своему воспевать величие Творца.

C момента детрансцендентизации данной культурной парадигмы начинается эпоха, символом которой по праву можно назвать Чувственность. Обычно этот процесс имманентизации датируют XVI-XVII вв. и связывают с Галилеем (Э. Гуссерль [23]), Декартом (М. Хайдеггер [6]). Но не менее симптоматичным выступает творчество Дж. Локка [24], который, на наш взгляд, развивает старую британскую номиналистическую традицию. Английский философ был убежден, что нет ничего в разуме, чего раньше не было бы в чувствах, казалось бы, не новая для интеллектуальной истории Запада позиция. Дунс Скот доказывал очень схожее положение, а гораздо раньше Аристотель говорил, что душа подобна чистой табличке. Однако разница в этих трех философемах колоссальная: Дунс Скот признавал важное значение чувственности, но при этом верил в реальное существование общих понятий, как минимум, в уме Бога. Аристотель же хоть и представлял душу tabula rasa, однако отнюдь не считал, что написать что-либо на ней способны только чувства. Для Локка же, чтобы стать общим понятием, которым оперирует разум, нужно пройти через чувственность. Уже для Дж. Беркли ощущения становятся не только критерием истины, но и существования. Согласно Беркли, существовать значит быть воспринимаемым [25]. Юму осталось сделать небольшой шаг, поставив под сомнение само понятие субстанции и причинности.

В апелляции к интеллектуальной очевидности как последнему критерию и обоснованию (в мысленном эксперименте Г. Галилея [26], cogito ergo sum P. Декарта [27], ощущениях Дж. Локка [24]) можно увидеть своеобразный «антропологический поворот», ставший основой научного мировоззрения и всей техногенной цивилизации.

Пытаясь преодолеть юмовский скептицизм, И. Кант [28] (а далее И. Фихте [29]) на самом деле только способствовал тому, чтобы данная философема приобрела законченный, еще более утонченный вид. Ирония истории: трансценденталист и рационалист канонизировал чувственность как фундамент познавательной способности. Можно говорить, что кантовские 
регулятивные идеи не нуждаются в чувственных данных или что категории оформляют опыт, который бы без деятельности рассудка был обречен на вечную бесформенность, но также очевидно, что без трансцендентальной эстетики не было бы трансцендентальной диалектики, а форма категорий навсегда осталась бы бессодержательно пустой. Таким образом, мир оказался погружен внутрь человеческой познавательной способности, единственным внешним «органом» которой является чувственность. Истина же не познается, а производится: как истину субъект извлекает из эмпирической действительности то, что раньше сам в нее вложил.

Разум и рассудок в понимании, характерном для описанных выше эпох, оказались ненужными. После секуляризации культуры нечего стало созерцать умным зрением, не к чему стало восходить ищущему последнюю истину рассудку. Разум и рассудок стали частью познавательной способности субъекта, призванные организовывать эмпирический материал. Всем эпохам до современной были известны два вектора духовного движения: один - нисходящий из трансцендентности в имманентность (эманация, любовь божья); второй (противоположный) - восходящий из чувственного мира в сверхчувственный (экстаз, блаженство). Для эпохи, символом которой выступает чувственность, первый вектор стал чужд (запрещен) абсолютно, второй - комфортно разместился в рамках социальной действительности и принципиально не способен ее покинуть. Соответственно этому принципу изменились и формы всех культурных практик.

Каким-то непостижимым образом (на самом деле, вполне постижимым!) изменчивые тени мира становления, «шумы» и «помехи» в мире вечных платоновских идей, превратились в желанный объект научного поиска. То, чего мог не заметить у себя под ногами Фалес, оказалось в фокусе, объективе, под микроскопом. «Прочь от метафизики к позитивному знанию!» - такими призывами были переполнены манифесты новой эпохи, причем под «позитивным» понималось знание, полученное именно через чувственность. Участники Венского кружка вообще объявили метафизику несуществующей. Такой себе апофеоз эпохи чув- ственности - объявить всё созданное разумом и рассудком фантомом ${ }^{3}$ !

Ничто не имеет значения кроме тела и его восприятий. Значимо то, что чувствуется здесь область фактов, протокольных предложений, базисного знания. Э. Юнгер констатирует: в новой реальности «тело тождественно с самой ценностью», а мир может заявить о себе исключительно с помощью боли, которой нужно избегать, «ибо тут боль задевает тело не как некий форпост, а подобно тому, как главная власть задевает существенное ядро самой жизни» [31, с. 489-490]. В мире, у которого отнята сфера трансцендентного, чувственность и ее предел в боли обретают метафизический вес: «В таком положении боль выступает как единственный критерий, который может дать надежные объяснения. Там, где не выдерживает никакая ценность, направленное на боль движение будет существовать как поразительный знак; в этом движении выдает себя негативный оттиск метафизической структуры», лишь подчеркивая принципиальную одномерность чувственную - новой реальности [31, с. 527].

То, чем во времена эпохи ума пренебрегали, чего сторонились, стало желанным и необходимым. Движение и изменения считались признаком несовершенства и иллюзорности, сегодня же именно в них видят один из критериев социального статуса и принадлежность к определенной ступени общественной иерархии. Сегодня скорость изменений стала чуть ли не главной культурной ценностью. Машина должна разгоняться до предельных скоростных показателей, по-настоящему современный

3 Поскольку смысл каждого научного высказывания должен быть установлен через сведение к какому-нибудь высказыванию о непосредственно данном (das Gegebene), то и смысл каждого понятия, к какой бы отрасли науки оно ни принадлежало, должен быть установлен через пошаговое сведение к другим понятиям, вплоть до понятий самой низшей ступени, которые относятся к непосредственно данному. Если бы такой анализ был осуществлен для всех понятий, то они тем самым были бы упорядочены в некоторую систему сводимости (Rückführungssystem), «конституирующую систему». Исследования конституирующей теории показывают, что в самых низших слоях этой системы находятся понятия, выражающие собственно психические переживания и качества; над ними располагаются физические объекты; из них образуются внепсихические предметы, а в самом конце - предметы социальных наук [30, с. 167]. 
человек должен следить за новинками, например, аксессуаров, и как только выходит новая модель - срочно ее покупать, а потом еще и, надеясь, что сделал это первым из своего круга знакомых, похвастаться приобретением, подтверждая свой социальный статус. Бытовая техника может работать на порядок дольше, но, исходя из психологической установки необходимости обновлений, должна быть заменена на технику следующего поколения. Перемены коснулись всех сфер культурного бытия современного человека, сегодня без проблем можно изменить внешность, некоторые части тела стали рассматриваться их хозяевами как, например, обувь, которую можно менять в зависимости от погоды, сам пол человека, полученный при рождении, перестал быть детерминантой. Как только из культуры исчезла константа (трансцендентность), ничего больше не осталось, как константой провозгласить изменения.

Своеобразным символом античной эпохи Разума и снисхождения идей в дольний мир может служить образ Прометея - если бы не его дерзкий поступок, человек никогда бы не смог прикоснуться к миру богов. Для средневековой эпохи Рассудка эмблематичным является подмеченный исследователями параллелизм между бесконечными циклами схоластической дискуссии и готическими формами - суммы теологии пытались собрать все доступное человеку знание в единый свод, но именно на то же, по мысли Э. Панофского, была направлена символика готических соборов: «В своей образности собор Высокой Готики стремился воплотить все Христианское знание - теологическое, естественнонаучное и историческое, где все элементы должны находиться каждый на своем месте...» [32, с. 70]. Когда же мир стал одномерно имманентным, лучшей стратегией взаимодействия с ним оказалось ощущение, испытываемое телом. Молодость, тренированность, чувственность - ключевые слова нового культурного текста, ощущать мир по полной - вот главный культурный принцип современности. Символом эпохи Чувственности стали «герои нашего времени» - прожигатели жизни, такие, например, как Ким Кардашьян или Пэрис Хилтон. Вечно загорелые, спортивные, сексапильные, принципиально не стареющие, всег- да улыбающиеся и довольные жизнью, в компании представителей противоположного пола, беспрерывно наслаждающиеся на частных яхтах или на самых дорогих курортах, пробуют мир на вкус, услаждают слух, экспериментируют с тактильностью, радуют глаз. А сотни миллионов их последователей (подписчиков в социальных сетях) беспрерывно наблюдают за этими картинами воплощенного рая и в меру своего понимания и возможностей пытаются их копировать.

Другим примером культурных практик эпохи чувственности являются технологии наслаждения. Наверное, никакая другая эпоха не знает такого количества культурных индустрий, направленных на получение наслаждений, рассчитанных на любого потребителя: гастрономия каких-угодно регионов и культур, алкоголь, наркотики, компьютерные игры, реалити-шоу, мыльные оперы, туризм (секс-туризм как один из самых распространенных его подвидов), предполагающий исключительно чувственность, культ сексуальности как таковой, караоке и т. д. Сам этос консюмеризма является ничем иным, как следствием этой культурной стратегии, как ни парадоксально, но сама целерациональность поставлена на службу чувственности: от пульта дистанционного управления телевизором до космических путешествий туристов.

Чувственность предполагает пассивное, страдательное положение, и любое напряжение для отыскания истины, свойственное умозрению и рассуждению, чуждо ей. Потому и наслаждения сегодня построены по принципу пассивного восприятия. Наверное, одним из предельных уровней реализации такой стратегии являются турецкие отели по системе all inclusive, где главное предназначение туриста - быть пассивным потребителем благ. Как по конвейеру отдыхающий должен передвигаться от одного приема пищи через жаренье на солнце к другому, сдабривая все это дешевым алкоголем, просматривая такого же качества развлекательные шоу, чтобы на следующий год повторить тот же путь.

Получение чувственного удовольствия является самым легким способом наслаждения: пассивная позиция не предполагает усилий, и оно доступно практически всем, вне зави- 
симости от достатка или социального статуса. Платон говорил, что ничего не может сравниться с наслаждением от видения блага, однако выработка способности такого созерцания большая работа, сегодня же она на маргинесе модного мейнстрима.

Таким образом, история Запада предстала в виде трех эпох, символами которых, в зависимости от способа получения истины, являются: Ум, Рассудок, Чувственность. Вокруг них вырабатываются определенные стержневые смыслы и культурные практики, в конечном итоге на их основе оформляется и сам тип культуры.

\section{Список источников}

1. Гегель Г.В.Ф. Феноменология духа. Санкт-Петербург : Наука, 2015. 443 с.

2. Шеллинг Ф.В.Й. Система мировых эпох : Мюнхенские лекции 1827-1828 гг. в записи Эрнста Ласо. Томск : Водолей, 1999. 320 с.

3. Маркс К. К критике политической экономии // Маркс К., Энгельс Ф. Соч. 2-е изд. Москва : Политиздат, 1959. Т. 13. С. 1-167.

4. Шnенглер О. Закат Европы. Новосибирск : Наука, 1993. 592 с.

5. Тойнби А. Постижение истории. Москва : Прогресс, $1991.736 \mathrm{c}$.

6. Хайдеггер М. Бытие и время. Санкт-Петербург : Наука, 2006. 466 с.

7. Ясперс К. Философия : в 3 кн. Москва : Канон+; РООИ «Реабилитация», 2012. 384 с.

8. Фукуяма Ф. Конец истории и последний человек. Москва : Ермак ; АСТ, 2005. 592 с.

9. Рорти Р. Случайность, ирония и солидарность. Москва : Русское феноменологическое общество, 1996.282 с.

10. Латур Б. Нового времени никогда не было : Эссе по симметричной антропологии / пер. с фр. Д.Я. Калугина ; науч. ред. О.В. Хархордин. Санкт-Петербург : Изд-во Европейского ун-та в С.-Петербурге, 2006. 240 с.

11. Козловский П. Философские эпопеи. Об универсальных синтезах метафизики, поэзии и мифологии в гегельянстве, гностицизме и романтизме // Судьбы гегельянства : философия, религия и политика прощаются с модерном. Москва : Республика, 2000. С. 348-373.

12. Конт О. Курс позитивной философии // Антология мировой философии. Москва : Мысль, 1970. T. 3. C. $553-577$.
13. Данилевский Н.Я. Россия и Европа : Взгляд на культурные и политические отношения Славянского мира к Германо-Романскому. СанктПетербург : Изд-во С.- Петербург. ун-та ; Глаголь, 1995.552 с.

14. Сорокин П.А. Социокультурная динамика // Сорокин П.А. Человек. Цивилизация. Общество. Москва : Политиздат, 1992. С. 425-504.

15. Платон. Диалоги / [пер. с древнегреч. В.С. Соловьева]. Москва : РИПОЛ классик, 2016. 576 с.

16. Плотин. Шестая эннеада: трактаты VI-IX. Санкт-Петербург : Изд-во Олега Абышко, 2016. 416 c.

17. Аристотель. Метафизика. Москва: Издательство «Э», 2016. 448 c.

18. Лосев А.Ф. История античной эстетики. Софисты. Сократ. Платон. Москва : Ладомир, 1994. 716 с.

19. Фома Аквинский. Сумма Теологии. Москва : Ника-Центр, 2005. 576 с.

20. Иоанн Дунс Скот, блаж. Избранное. Москва : Изд-во францисканцев, 2001. 584 с.

21. Оккам У. Избранное. Москва : Ленанд, 2015. $280 \mathrm{c}$.

22. Бэкон $P$. Великое сочинение [Электронный ресурс] // Восточная литература : Средневековые исторические источники Востока и Запада. URL: http://www.vostlit.info/Texts/rus15/ Bacon_Roger/frametext1.htm (дата обращения: 30.05.2018).

23. Гуссерль Э. Кризис европейских наук и трансцендентальная феноменология : Введение в феноменологическую философию. Санкт-Петербург : Наука, 2013. 494 с.

24. Локк Дж. Опыт о человеческом разумении / пер. с англ. А.Н. Савина // Локк Дж. Сочинения : в 3-х т. Москва : Мысль, 1985. Т. 1. 623 с. ; Т. 2. $560 \mathrm{c}$.

25. Беркли Дж. Трактат о принципах человеческого знания / Дж. Беркли. Сочинения. Москва : Наука, 1978. С. 152-247.

26. Галилей Г. Диалог о двух главнейших системах мира - Птолемеевой и Коперниковой. Москва ; Ленинград : ОГИЗ - СССР, 1948. 380 с.

27. Декарт Р. Сочинения. Санкт-Петербург : Наука, 1992.656 с.

28. Кант И. Критика чистого разума. Москва : Эксмо, 2016. 736 с.

29. Фихте И.Г. Основа общего наукоучения [Электронный ресурс] // Цифровая библиотека по философии. URL: http://filosof.historic.ru/books/ 
item/f00/s00/z0000076/st000.shtml (дата обращения: 30.05.2018).

30. Карнап P., Хан Х., Нейрат О. Научное миропонимание - Венский кружок // Аналитическая философия / под ред. М.В. Лебедева, А.З. Черняка. Москва : РУДН, 2006. 622 с.
31. Юнгер Э. О боли // Юнгер Э. Рабочий. Господство и гештальт. Санкт-Петербург : Наука, 2002. C. 471-527.

32. Панофский Э. Готическая архитектура и схоластика // Богословие в культуре средневековья. Киев : Путь к истине, 1992. С. 49-78.

\section{The Logic of the West's History: Three Ages}

\section{Viktor S. Levitsky}

Ukrainian Institute of Strategies of Global Development and Adaptations, 68-a, Sechevykh Streltsov Str., Kiev, 04050, Ukraine

E-mail: uisgda@gmail.com; victor2609@ukr.net

Abstract. The postmodern turn of the last quarter of the twentieth century, which consisted in a final rejection of metanarratives, makes great philosophical systems one of the areas of mythological narratives. However, this fact does not mean we do not have to comprehend the modern situation, which has become an inalienable attribute of modern identity. In this way, generalized metaphors, generalizing our knowledge at the intuitive level of aesthetic perception, become more and more important. From this philosophical and metaphorical instrumentation's point of view, the history of the West can be schematically described in the form of three ages, symbolized, respectively, by the Mind (intelligence), the Reason, and the Sensuality, each of them having their own unique system-forming meanings that suggest relevant cultural practices. The Mind, or the age of Antiquity, affirms the identity of the unconcealed in reality with the ontological basis of the existing the cosmic mind. The Christian Middle Ages raise the line between the world of divine archetypes and sinful empirism. The Reason becomes human's symbol and destiny. The new age or Modernity focuses on what is happening here and right now, brings reality to the momentary and pragmatic, and therefore can be described as the age of Sensuality. Thus, the logic of the West's history, understood in this way, allows us to look at the whole historical process from a new perspective, at the same time opposing it (the logic) to the classical view, which became classical in the times of $M$. Weber, on history as on an ongo- ing process of disenchantment, the result of which is the mankind teleologically moving towards the incarnation of formal rationality.

Key words: reality, identity, sensuality, reason, mind, age.

Citation: Levitsky V.S. The Logic of the West's History: Three Ages, Observatory of Culture, 2018, vol. 15 , no. 3, pp. $260-270$. DOI: $10.25281 / 2072-$ 3156-2018-15-3-260-270.

\section{References}

1. Hegel G.W.F. The Phenomenology of Spirit. St. Petersburg, Nauka Publ., 2015, 443 p. (in Russ.).

2. Schelling F.W.J. Sistema mirovykh epokh: Myunkhenskie lektsii 1827-1828 gg. v zapisi Ernsta Laso [The System of World Ages: The Munich Lectures of 1827-1828, Recorded by Ernst Lasaulx]. Tomsk, Vodolei Publ., 1999, 320 p.

3. Marx K. A Contribution to the Critique of Political Economy, Marx K., Engels F. Works. Moscow, Politizdat Publ., 1959, vol. 13, pp. 1-167 (in Russ.).

4. Spengler O. The Decline of the West. Novosibirsk, Nauka Publ., 1993, 592 p. (in Russ.).

5. Toynbee A. A Study of History. Moscow, Progress Publ., 1991, 736 p. (in Russ.).

6. Heidegger M. Being and Time. St. Petersburg, Nauka Publ., 2006, 466 p. (in Russ.).

7. Jaspers K. Filosofiya: $v 3 \mathrm{kn}$. [Philosophy: in 3 books]. Moscow, Kanon+ Publ., ROOI "Reabilitatsiya" Publ., 2012, 384 p.

8. Fukuyama F. The End of History and the Last Man. Moscow, Ermak Publ., AST Publ., 2005, 592 p. (in Russ.)

9. Rorty R. Contingency, Irony, and Solidarity. Moscow, Russkoe Fenomenologicheskoe Obshchestvo Publ., 1996, 282 p. (in Russ.).

10. Latour B. We Have Never Been Modern. St. Petersburg, Evropeiskogo Universiteta v Sankt-Peterburge Publ., 2006, 240 p. (in Russ.). 
11. Kozlovsky P. Philosophical Epics. On the Universal Syntheses of Metaphysics, Poetry and Mythology in Hegelianism, Gnosticism and Romanticism, Sud'by gegel'yanstva: filosofiya, religiya i politika proshchayutsya s modernom [The Fates of Hegelianism: Philosophy, Religion and Politics Say Goodbye to Modernity]. Moscow, Respublika Publ., 2000, pp. 348-373 (in Russ.).

12. Comte A. The Course in Positive Philosophy, Antologiya mirovoi filosofii [Anthology of World Philosophy]. Moscow, Mysl' Publ., 1970, vol. 3, pp. 553577 (in Russ.).

13. Danilevsky N.Ya. Rossiya i Evropa: Vzglyad na kul'turnye i politicheskie otnosheniya Slavyanskogo mira $k$ Germano-Romanskomu [Russia and Europe: A Look at the Cultural and Political Relations of the Slavic World to the German-Roman One]. St. Petersburg, Sankt-Peterburgskogo Universiteta Publ., Glagol' Publ., 1995, 552 p.

14. Sorokin P.A. Sociocultural Dynamics, Sorokin P.A. Chelovek. Tsivilizatsiya. Obshchestvo [Sorokin P.A. Man. Civilization. Society]. Moscow, Politizdat Publ., 1992, pp. 425-504 (in Russ.).

15. Plato. Dialogues. Moscow, RIPOL Klassik Publ., 2016, 576 p. (in Russ.).

16. Plotinus. The Sixth Ennead: Treatises VI-IX. St. Petersburg, Olega Abyshko Publ., 2016, 416 p. (in Russ.).

17. Aristotle. Metaphysics. Moscow, "E” Publ., 2016, 448 p. (in Russ.).

18. Losev A.F. Istoriya antichnoi estetiki. Sofisty. Sokrat. Platon [The History of Ancient Aesthetics. The Sophists. Socrates. Plato]. Moscow, Ladomir Publ., 1994, 716 p.

19. Thomas Aquinas. Summa Theologica. Moscow, Nika-Tsentr Publ., 2005, 576 p. (in Russ.).

20. Duns Scotus. Selected Works. Moscow, Frantsiskantsev Publ., 2001, 584 p. (in Russ.).

21. Ockham W. Selected Works. Moscow, Lenand Publ., 2015, 280 p. (in Russ.).
22. Bacon Roger. Opus Majus, Vostochnaya literatura: Srednevekovye istoricheskie istochniki Vostoka i Zapada [Oriental Literature: Medieval Historical Sources of East and West]. Available at: http://www.vostlit. info/Texts/rus15/Bacon_Roger/frametext1.htm (accessed 30.05.2018) (in Russ.).

23. Husserl E. The Crisis of European Sciences and Transcendental Phenomenology: An Introduction to Phenomenological Philosophy. St. Petersburg, Nauka Publ., 2013, 494 p. (in Russ.).

24. Locke J. An Essay Concerning Human Understanding, Locke J. Works: in 3 volumes. Moscow, Mysl' Publ., 1985, vol. 1, 623 p., vol. 2, 560 p. (in Russ.).

25. Berkeley G. A Treatise Concerning the Principles of Human Knowledge, G. Berkeley. Works. Moscow, Nauka Publ., 1978, pp. 152-247 (in Russ.).

26. Galilei G. Dialogue Concerning the Two Chief World Systems. Moscow, Leningrad, OGIZ - SSSR Publ., 1948, 380 p. (in Russ.).

27. Descartes R. Sochineniya [Works]. St. Petersburg, Nauka Publ., 1992, 656 p.

28. Kant I. Critique of Pure Reason. Moscow, Eksmo Publ., 2016, 736 p. (in Russ.).

29. Fichte J.G. Foundations of the Science of Knowledge, Tsifrovaya biblioteka po filosofii [Digital Library on Philosophy]. Available at: http://filosof. historic.ru/books/item/f00/s00/z0000076/st000. shtml (accessed 30.05.2018) (in Russ.).

30. Carnap R., Hahn H., Neurath O. The Scientific Worldview - Vienna Circle, Analiticheskaya filosofiya [Analytical Philosophy]. Moscow, RUDN Publ., 2006, 622 p. (in Russ.).

31. Jünger E. On Pain, Jünger E. Worker. Domination and Gestalt. St. Petersburg, Nauka Publ., 2002, pp. 471-527 (in Russ.).

32. Panofsky E. Gothic Architecture and Scholasticism, Bogoslovie v kul'ture srednevekov'ya [Theology in the Culture of the Middle Ages]. Kiev, Put' k Istine Publ., 1992, pp. 49-78 (in Russ.). 